\title{
The work of Judita Cofman on Didactics of Mathematics ${ }^{2}$
}

\begin{abstract}
Judita Cofman was the first generation student of mathematics and physics at Faculty of Philosophy in Novi Sad, Serbia, and the first holder of doctoral degree in mathematics sciences at University of Novi Sad. Her PhD thesis as well as her scientific works until the end of 70's belongs to the field of finite projective and affine planes and the papers within this topic were published in prestigious international mathematical journals. The aim of this paper is to draw attention to Cofman's contribution in didactics and teaching of mathematics through the activities with young mathematicians, to whom she devoted the second part of her life and scientific work. Her reflections on importance of geometry based on her experiences with high school students are specially pointed out.
\end{abstract}

Key words: Judita Cofman, teaching of mathematics, didactics of mathematics.

\section{Introduction}

Mathematician Judita Cofman ${ }^{3}$ was born in Vršac on 4th June 1936. She came from a well-known and formerly wealthy family of Zoffmanns whose arrival in Vršac is put at the time of the reign of Maria Theresa of Austria (1717-1780) where they came from a German region with a strong beer brewing tradition (Kuručev, 2007: 157-163). Although the

\section{1 nikaca@uns.ac.rs}

2 Writing of this article was supported by Ministry of Education, Science and Technological Development of Republic of Serbia through Projects III44006 and ON174026.

3 Her name was entered into the Official Register as Judit Zoffmann, but in the documents of Yugoslavia of that time her name was written in its Serbian rendition as Judita Cofman, and that was the name she used for the rest of her life.
Zoffmanns were originally German, they gradually adopted Hungarian identity, so Judita declared herself as a Hungarian from Vojvodina. An environment of material and cultural wealth marked the life of Judita's father Ákos Zoffmann (1910-1974). Having received wide education in Germany, he became a great expert in beer brewing, and wine growing and storing industries. Judita's mother Lujza (19102000), born Kozics, comes from a Hungarian family of lawyers from her father's side, while her mother came from Vršac. Lujza's grandfather was a mathematics teacher at the Vršac Grammar School, and her uncle was the mayor of the town of Vršac. Despite the incertitude and horrors of World War II, Judita enjoyed a happy childhood at her family home. She went to primary school in Hungarian and later to Serbian Grammar School in her hometown. The 
family home, full of love and harmony, installed in her a great feeling that work, study, reading, as well as the knowledge of foreign languages are necessary preconditions for success in life. Besides being gifted for mathematics, Judita had a talent for languages, so, besides her mother tongue of Hungarian and the official Serbian language, as a child she learned German, Russian and, which was rare at that time, English. She later learned French and Italian.

Judita Cofman's $\mathrm{PhD}$ thesis as well as her scientific work till the end of 70's belongs to the theory of finite projective planes, Möbius planes and Sperner's spaces - a very up-to-date and lively mathematical field closely related to algebra and group theory. Her results within these topics were published in prestigious international mathematics journals ${ }^{4}$ and were presented at high ranking conferences. ${ }^{5}$ Her results complemented the results of many great geometricians of the early 20th century on the one hand, and on the other, the active follow-up and advancement of certain subfields of projective geometry rest upon her results (Nikolić, 2012). In the second period of 20 years, from 1980 till 2001, Judita was completely devoted to the mathematical education and didactics of mathematics and improvements in teaching process, especially working with gifted teenage mathematicians.

\section{Studies and career}

Judita Cofman started mathematical studies in 1954, graduating with the highest grades in 1958. She was among 66 students enrolled as the first generation of students of mathematics at the Faculty of Philosophy in Novi Sad. They were all studying to

4 Mathematische Zeitschrift, Archives Mathematica, Canadian Journal of Mathematics, for example (Nikolić, 2012: 97).

5 Colloquio Internazionale sulle Teorie Combinatorie (1973) held in Rome, Atti del Convegno di Geometria Combinatoria e sue Applicazioni (1970) held at the University of Perugia and the International Conference on Projective Planes - Dedicated to the memory of Peter Dembowski (1973) held at the Washington State University (Nikolić, 2012: 95). be teachers of mathematics. At that time the majority of classes were given by professors from the University of Belgrade, academicians Miloš Radojčić, Anton Bilimović, Radivoje Kašanin and Jovan Karamata (professor in Geneva at the time). Among the mathematicians from Novi Sad, there were Mirko Stojaković and Bogoljub Stanković, while the first assistants were Vojislav Marić and Mileva Prvanović. They were all to become eminent Serbian scientists and members of Serbian Academy of Sciences and Arts. The first elected Assistant Professor at the Mathematics Department was Mileva Prvanović (1956), who taught in the field of geometry. Judita Cofman was appointed as her Assistant in 1960. Judita had been the best student of mathematics at the university for generations, or so the story goes (Nikolić-Despotović, 2004; 14). Her younger fellowstudents, later professors at the University of Novi Sad, Irena Čomić and Danica Nikolić Despotović, remember that students had great respect for professors but also some kind of fear for them. Despite all efforts of professors to travel from Belgrade, they were not always accessible to their students. The professional literature in Serbian language was still insufficient at that time, and students could not use foreign titles because their knowledge of English, French, German or Russian was modest. The only person who was able to answer at any moment a variety of questions by curious students, was Judita Cofman. As her knowledge of foreign languages was high, she was almost the only one among the students who could use German, English and Russian textbooks and widen her knowledge of mathematics, which she used to unselfishly share with her colleagues. They felt that she knew all there was to know about mathematics! As soon as she was made an Assistant teacher, in collaboration with students she published the lecture notes on Ruler-and-compass Constructions. This was the first publication in the field of mathematics issued at the Faculty of Philosophy in Novi Sad and as such heralds what was to become an abundant mathematics publishing activity at the University of Novi Sad. 
The following year, in 1961, she left to undertake postgraduate studies in Rome. There she studied with well-known Italian mathematician Professor Lucio Lombardo-Radice (1916-1982). As Lombardo-Radice contributed to finite geometry and geometric combinatorics together with Guido Zappa (1915) and Beniamino Segre (1903-1977), and wrote and published important papers concerning the Non-Desargues Plane, Judita Cofman chose the same field of mathematics for her scientific work. In 1963 she returned to Novi Sad defending her PhD thesis under the title Finite Non-Desargues Projective Planes Generated by Quadrangle, she took the first doctoral degree in mathematical sciences from the University of Novi Sad. The committee for her thesis defense consisted of Lombardo-Radice and professors Mirko Stojaković (mentor) and Mileva Prvanović.

As the holder of the Alexander von Humboldt scholarship she spent 1964/65 school year at the University of Frankfurt/Main. The following six years she spent as a lecturer professor at Imperial College in London (University of London), where she was also engaged in her research work. In 1970 she was a visiting professor at the University of Perugia (Italy). From 1971 to 1978 she taught mathematics at the universities in Tübingen and Mainz. During this period she took part in three major conferences - International Colloquio on Combinatorial Theory held in Rome, Combinatorial Geometry and Applications held at the University of Perugia and the International Conference on Projective Planes held at the Washington State, which hosted all the important mathematicians of that time whose field of work involved Projective Planes.

From 1978 till 1993 she worked at the state Putney High School in London and became interested in the teaching and methodology of mathematics at secondary level. The academic year 198586 she stayed at St. Hilda's College, Oxford, during which she enjoyed the teacher fellowship. She spent these six years professionally absolutely dedicated to the pedagogical-methodological work with teachers of mathematics and talented students. Judita also taught on several advanced master classes held at the City of London School, together with teachers Terry Heard and Martin Perkins. In 1987 she was the member of training staff of the British Olympic team at 28th International Mathematical Olympiad held on Cuba. ${ }^{6}$ In April 1993 she participated at Second German meeting of the European Woman in Mathematics in Tübingen with a talk On the role of problem solving in math classes. She collaborated with several foundations and associations (Sir John Cass Foundation, Advanced Royal Institution Mathematical Classes, Association of Gifted Children in Great Britain). She was organizer, and active participant and lecturer of several inspirational International summer camps for young mathematicians. The number of people that attended the maths camps was also coached by Judita in preparation for the Maths Olympiads (Jeroen Nijhof, Anders Bjorn and Alex Selby for example).

She was the editor of journal Hypotenuse which was populated by articles closely connected to her seminars at these camps. She also gave regular seminars in Germany for teachers of mathematics and students preparing to become teachers, as well as lectures within didactics seminars (Didaktik der Mathematik - Seminar der Universität Freiburg). ${ }^{7}$

6 The report by Mr. Robert Lyness, leader of the British team at 28th International Mathematical Olympiad, Cuba 1987 tells us of this occassion: "Our team was selected by means of the $\mathrm{Na}$ tional Mathematics Contest and the British Mathematical Olympiad, followed by some postal tuition and a residential selection/training session which included a further test. This session was held at the Ship Hotel, Reading, from Friday 8th May to Sunday 10th May 1987. It was staffed by Judita Cofman, David Cundy, Terry Heard, John Hersee, Paul Woodruff, and myself. The training programme consisted of short lectures and tutorial periods during which the participants had opportunities to expound their own solutions to problems. It proved extremely helpful. All these activities are the responsibility of the Mathematical Association>s National Committee for Mathematical Contests.»

7 Mathe mal anders, Freizeitaktivitäten für Schüler und Studenten, lecture held on the $5^{\text {th }}$ of December 1995. 
From 1993 until her retirement in august 2001 she worked as the professor of didactics of mathematics at University of Erlangen, Nürnberg and became the head of the Mathematics Teaching Methods Department there (Prvanović, 2002; 57). In her spare time she conducted Maths-Workshops for 13-19 years old youngsters. About her experience gained during these Workshops it could be heard and seen from the video being recorded at the FAU College Alexandrinum (Collegium Alexandrinum) as a part of Projekt Uni-TV. Judita Cofman gave the talk Mathematik macht Spass! - Über Workshops für Gymnasial schülerinnen und-schüler am Mathematischen Institut on 24th of June 1999. ${ }^{8}$ In September 2001 she was invited to participate in the work of the Postgraduate Studies Department for Mathematics Teaching Methods and appointed a professor at the Faculty of Natural Sciences at University Kossuth Lajos in Debrecen, Hungary, where she passed away on 19th December of the same year.

\section{Work in the Field of Mathematical Education}

The second period of Judita Cofman's life and scientific work, from 1980 till 2001, was marked by theory and practice in the field of pedagogy and didactics of mathematics dedicated to students and their teachers. In this scientific engagement there were no momentary ascents of mind and creation of new systems, no new theories nor proving theorems or conjectures; what mattered to her seems to had been an overall understanding of teaching mathematics, approach to students and different teaching methods through a well-balanced division between theory and problems designed to motivate students to think and work independently on solving them. Judita Cofman possessed all the preconditions to be successful in the methods of teaching mathematics she was a mature personality, her mathematical ability was proven by his publication record, and most

8 See the Web page http://www.university-tv.de/ca.html or directly the video of her talk http://giga.rrze.uni-erlangen.de/ movies/collegium alexandrinum/ss99/19990624.mpg importantly, she cherished the deep and true love for children and their learning.

Judita Cofman collaborated with a number of universities around the world in preparing future mathematical teachers, and had an intensive cooperation with mathematics institutes and various associations of mathematicians. She constantly emphasized the importance of the quality of teaching of mathematics, from the lower grades of elementary school to university level. She was known for being an exceptionally good teacher, who had a very responsible attitude towards her profession, which was the result of her great respect for her audiences and the science of mathematics, and she prepared thoroughly for her lectures. In 1984 Judita started an intensive collaboration with associations and methodological centers dedicated to teaching in the Hungarian language in Vojvodina. Her work is known in Hungary as well. She maintained a close contact with the universities in Budapest, Szeged and Debrecen in Hungary, and took part in the work of camps for talents and future teachers of mathematics.

The central problem of her engagement in didactics of mathematics was how to motivate pupils to think and work independently on their solutions even at an early age. ${ }^{9}$ Judita Cofman thought that one way of introducing youngsters to independent study was to get them involved in work on projects. One such example was her well known International Camps for young mathematicians held in England and Germany (Cofman, 1990; preface and Cofman, 1986; Gardiner and Jones, 1985). The contents and organization of her well-known book What to solve? - Problems and suggestions for young mathematicians, is a compilation of problems and solutions discussed during seminars and sessions on problem solving in these camps. The organization of the text, selecting and grouping of questions, comments, references to related mathematical topics and instructions on teaching, represent the core of Judita's ideas on the teaching of mathematics. During the process

9 Cofman (2000). 
of solving problems and finding answer to the given question, campers-pupils and readers of her book were guided gradually step by step by encouraging independent thinking and researching, as well as through the variety of approaches to problem solving.

The atmosphere at the camp held in the summer of 1984, near Chelmsford in Essex is described well by Heather Cordell, at the time a fifteen-yearold girl from London. ${ }^{10}$ Here it is her account:

"Like its predecessors, the camp in 1984 proved to be a resounding success. This was in no small way helped by the fact that its participants came from all over Europe, from nine different countries altogether, each bringing his/her own way of looking at mathematics and tackling mathematical problems. An average working day at the camp would start at 9:00 a.m. with a demonstration of problem-solving techniques. These problems varied from day to day in both standard and topic, so that a wide variety of interest and ability could be catered for. Examples included a proof of the existence of an infinite number of primes, ways of solving problems by the 'pigeon hole principle', and many others. Next came a session of project work. The projects were stimulated by particular problems (from a list provided) or were chosen by the students themselves. A practical interest in bell-ringing inspired one participant to investigate the various permutations possible on a certain set of bells. Many of the projects were a result of combined efforts; a more advanced student could often use his/her knowledge to work with a less advanced but equally dedicated student. In the second week, the students themselves led discussions about their results and diffi-

10 Heather Cordell is today Professor of Statistical Genetics and a Welcome Senior Research Fellow in the Institute of Human Genetics at Newcastle University, UK. When she was once asked about who contributed to her becoming a scientist, among others, mostly professors and colleagues from University, she mentioned Judita Cofman as her high school mathematics teacher (See her text from 2003: Moving from Promise to Proficiency, The Scientist, 17 (8), 56.). culties with their projects. The first afternoon session lasted from 3:00 p.m. to 4:00 p.m., and consisted of a lecture a guest speaker or one of the tutors. The topics again varied, but usually involved some less traditional subjects such as codes and ciphers, non-conventional geometries, topology and ways to win Nim. The lecture contents would be expanded in the second afternoon session, from 5:00 p.m. to $6: 00$ p.m., to give more insight for the advanced participants. The fourth session was not compulsory - but many younger students did attend and enjoy what they could understand. Of course, there were many other opportunities for both relaxation and study. These included a visit to London (alternatively a country walk for those who preferred), an invitation watch the local bell-ringing and day spent in Cambridge, with two excellent lectures on Convex sets and their applications in Economics and Algorithms. All in all, everyone had a most enjoyable fortnight and is looking forward to participating again next year".

In her article On the Role of Geometry in Contemporary Mathematical High School Education (1996b), Judita Cofman listed remarks concerned primarily to geometry, based on her experiences with high school students:

1. In the contemporary education, with a curriculum overburdened with details from various fields of mathematics, there is a danger that the study of mathematics can stray into memorizing facts and a mechanical learning of algorithms. Contrary to this, the efforts should be directed at pupils' understanding the existing links between the phenomena they encounter in different fields of mathematical study. Geometry can play a certain role in such efforts, because the mathematical disciplines taught in high school are rich in details for which there are geometrical illustrations appropriate to the pupils' age. The application of such illustrations, on the one hand, facilitates the process of understanding of the totality of teaching material, and on the 
other, presents geometry as a science of an actual importance.

2. The importance of Euclidean geometry in teaching is supported by the fact that the shapes of this geometry are encountered in our living environment. The study of space is particularly facilitated by the study of solid geometry, which is, unfortunately, often neglected in syllabus and curriculum. There is an important fact in respect to geometrical features of space which is often forgotten; the majority of children possess a lot of elementary knowledge about objects, such as the cube or the sphere from the earliest age. This elementary knowledge can be extremely useful for introducing notions such as: defined and undefined elements, axioms and theorems, necessary and sufficient conditions, etc. All these notions are important for the field of mathematics while the familiarity with space can be used to make pupils grasp the essence starting from concrete examples.

3. Mathematics is one of the earliest scientific disciplines, an important segment of human cultural heritage. This fact must be reflected on the teaching of mathematics: it is advisable to draw pupils' attention, whenever an opportunity arises, to their historical background. The history of geometry is an important part of the history of mathematics, not only because geometry is one of the oldest branches of mathematics. The importance of geometry mostly lies in the fact that there were several major problems in this field, starting from the Ancient Greek age, which could finally be solved only in the 19th century. The solutions to these problems had been sought for ages; the attempts led to a series of new discoveries and contributed to a further development of the entire science of mathematics. One of the famous problems of geometry was the so called Delian problem of doubling the cube.

4. Teaching of geometry can also play a useful role in illustrating the achievements in the most current fields of mathematics.
5. The knowledge gained in the study of geometry can contribute to a better understanding of the phenomena from different fields of natural sciences.

6. For teaching of geometry to be successful, teaching personnel must have a solid knowledge of this subject. However, not only at schools, but also in university courses and other pedagogical institutions for training future mathematics teachers, there is a tendency of neglecting the study of geometry. This fact can lead to a drastic deterioration in the level of geometry teaching at schools. What is needed is an effort at elevating the respectability of geometry with the students of mathematics.

\section{Conclusions}

In her pedagogical work, Judita Cofman had the ability to raise simple mathematical truths onto a higher level and turn the elementary into a science. She knew historical genesis of each problem, where it originated from and how it was solved throughout history. She deemed that an important reason for teaching mathematics in schools was to promote independent pupils' thinking processes and powers of observation. ${ }^{11}$ Throughout their schooling, pupils should be made aware of the links between various phenomena and they should be given the opportunity to discover these links on their own whenever this is possible. Moreover, pupils should be motivated to search for interdependence between seemingly unrelated topics. How can this be achieved? The key answer to the above question and generally to teaching of mathematics she gave in several papers and five books dedicated to mathematics teaching methods, which represent an outstanding approach to solving non-standard mathematical problems. Her historical approach to science and mathematical problems was the focus of her books which feature problems based on famous topics from the history of mathematics and a selection of elementary problems treated by eminent twentieth-century mathematicians.

11 Cofman (1998). 


\section{Papers and books on mathematical education by Judita Cofman}

1. Cofman, J., 1981a. Problems for young mathematicians, Pullen (Knebworth), pp. 66.

2. Cofman, J., 1981b. Operations with Negative Numbers. Mathematics Teaching 94, 18-20.

3. Cofman, J., 1983. Mathematical Activities for Motivated Pupils. Gifted Education International, 2 (1), 4244.

4. Cofman, J., 1986. Thoughts around an international camp for young mathematicians. The Mathematical Intelligencer 8 (1), 57-58.

5. Cofman, J., 1990. What to solve? Problems and suggestions for young mathematicians. Oxford Science Publications. The Clarendon Press, Oxford University Press, New York,. xiv+250 pp.

6. Cofman, J., 1992. Verallgemeinerung der Fibonacci-Folge. Projekte für Schuelerzirkel. Praxis der Mathematik 34 (4), 157-160.

7. Cofman, J., 1994a. Šestougaonik ili kocka? Ispitivanje trodimenzionalnih objekata u osnovnoj školi (Serbian), [Hexagon or square? Investigation of three-dimensional objects in the primary school]. Nastava matematike XXXIX 1-4, 1-5.

8. Cofman, J., 1994b. Čas ponavljanja u jednoj školi u engleskoj sa jedanestogodišnjim učenicima (Serbian), [Class reps in a school in England with eighteen year students]. Nastava matematike XXXIX 1-4, 41-43.

9. Cofman, J., 1995a. Numbers and shapes revisited. More problems for young mathematicians. The Clarendon Press, Oxford University Press, New York, xii+308 pp.

10. Cofman, J., 1995b. Interplay of ideas in teaching mathematics. Proceedings of the 2nd Gauss Symposium. Conference A: Mathematics and Theoretical Physics (Munich, 1993), Symposim Gaussiana, de Gruyter, Berlin, 85-95.

11. Cofman, J., 1995c. Patterns of shape and numbers, 7th International Geometry Conference, Haifa, Israel, 1995. Zentralblatt für Didaktik der Mathematik, 27 (5), 153-156.

12. Cofman, J., 1996a. Bemerkungen zu Zuluagas Beweis des Satzes von Pythagoras. Praxis der Mathematik 38 (6), 269-270.

13. Cofman, J., 1996b. O ulozi geometrije u savremenom matematičkom obrazovanju u srednjoj školi (Serbian), [On the role of geometry in the modern mathematical education in high school]. Metodika i istorija geometrije, Matematički vidici 7, 12-25.

14. Cofman, J., 1996c. Lösungsmethoden einer Aufgabe ber ein Minimum. Praxis der Mathematik 38 (4), 180-181.

15. Cofman, J., 1997a. Catalan numbers for the classroom? Elemente der Mathematik 52 (3), 108-117.

16. Cofman, J., 1997b. Bestimmung der kleinsten einbeschrieben Quadrats. Praxis der Mathematik 39 (5), 205-207

17. Cofman, J., 1998. Explorations and discoveries in the classroom. The Teaching of Mathematics I-1, 23-30.

18. Cofman, J., 1999a. Einblicke in die Geschichte der Mathematik I. Aufgaben und Materialien für die Sekundarstufe I, (German) [Insight into the history of mathematics I. Problems and materials for lower secondary and teacher education], Sprektrum Akad. Verl., Heidelberg, 326 pp.

19. Cofman, J., 1999b. Über Aufgaben mit ‘beweglichen Elementen〉. Der Mathematikunterricht 45 (1), 37-51. 
20. Cofman, J., 1999c. La nice [lattice] paths with U-terms and generalized Pascal`s triangles. Octogon Mathematical Magazine 7 (1), 20-26.

21. Cofman, J., 2000. How to motivate 10-18 years old pupils to work independently on solving mathematical problems. The Teaching of Mathematics, Vol. III-2, 2000, 83-94. Plenarno predavanje Kako motivisati 10-18-godišnje učenike da u toku nastave samostalno rešavaju razne matematičke zadatke, 10. kongres matematičara Jugoslavije, Beograd 21-24. januar 2001. Nastava matematike XLVII-1-2, 2002, 11-23.

22. Cofman, J., 2001a. Einblicke in die Geschichte der Mathematik II. Aufgaben und Materialien für die Sekundarstufe II und das Lehramtsstudium. (German) [Insight into the history of mathematics II. Problems and materials for the upper secondary and teacher education], Sprektrum Akad. Verl., Heidelberg, 426 pp.

23. Cofman, J., Merkel, C., 2001b. Modelle zum Anfassen im Mathematikunterricht (German), [Geometric models for handling with], Mathematikunterricht (Seelze) 47 (2), 4-29.

24. Cofman, J., 2001a. Eigenschaften konvexer n-Ecke (German). [Properties of convex n-gons], Mathematik Lehren 105, 49-53.

25. Cofman, J., Pejić, S., 2002. Matematički projekti 4-5, uputstva za rešavanje zadataka sa napomenama i predlozima za nastavnike (Serbian), [Instructions for solving tasks with notes and suggestions for teachers], Eduka, Beograd, 14 pp.

\section{References}

- Gardiner, T. and Jones, L. (1985). Saturday morning maths. Mathematics in School, 14 (2), 35-37.

- Kuručev, D. (2007). Portreti Margit and Šandor Cofman [Portraits of Margit and Šandor Cofman]. Rad Muzeja Vojvodine, 49, 157-163.

- Nikolić, A. (2012). Mathematician Judita Cofman (1936-2001). Teaching Mathematics and Computer Science, 10 (1), 91-115.

- Nikolić-Despotović, D. and Prvanović, M. (2004). Judita Cofman - prvi doktor matematičkih nauka na Univerzitetu u Novom Sadu. Sveske Matice srpske 41 (12), 14-20.

- Prvanović, M. (2002). Judita Cofman (1936-2001), Obituary. The Teaching of Mathematics, 8, 57.

\section{др Александар М. Николић}

Факултет техничких наука, Универзитет у Новом Саду

\section{Дело Јудите Цофман у дидактици математике}

Математичарка Јудита Цофман (1936-2001) рођена је у Вршцу 4. јуна 1936. године. Потиче из познате и некада богате породице Zoffmann, чији су се преци половином 18. века доселили из Немачке у Вршац. Иако пореклом Немци, постепено су усвојили мађарски идентитет, па се Јудита, обично, изјашњавала као Мађарица из Војводине. Припадала је првој генерацији ђака уписаних 1954. године на студије математике и физике на Филозофском факултету у Новом Саду. Била је најбољи студент, не само у својој генерацији већ и генерацијама после ње. На последипломске студије одлази 1961. 
године у Рим. Тамо је студирала и учила код познатог италијанског математичара професора Лучија Ломбарда Радичеа. После две године проведене у Италији, враћа се у Нови Сад и брани докторат „Коначне недезаргове пројективне равни генерисане четворотемеником“, и тако остаје упамћена као први студент који је докторирао на теми из математичких наука на Универзитету у Новом Саду. У комисији на одбрани њене тезе били су, осим Ломбарда Радичеа, и професори Мирко Стојаковић (ментор) и Милева Првановић. Њена докторска дисертација, као и њен целокупни научни допринос до краја седамдесетих година прошлог века, припадају области коначних пројективних и афиних равни, а њени радови у оквиру ове теме објављени су у престижним међународним математичким часописима. Са Филозофског факултета, али и из своје земље, одлази 1964. године - прво на Империјални колеџ Лондонског универзитета (Велика Британија), од 1970. године гостујући је професор на Универзитету у Перуђи (Италија), а од 1971. до 1978. године предаје математику на универзитетима уТибингену и Мајнцу (Немачка). Почетком осамдесетих година прошлог века почиње да се интересује за проблеме наставе математике и више неће написати ниједан научни рад из претходне области којом се тако успешно бавила. Циљ нашег рада јесте да се скрене пажња на допринос Јудите Цофман у области педагогије и дидактике и методике математике кроз рад са младим математичарима, чему је у потпуности посветила други део свог живота и научних активности. Она је поседовала све предуслове да буде успешна и у методици и настави математике јер је била формирана личност, доказани математичар, и што је најважније, неговала је дубоку и истинску љубав према деци. Централни проблем њених активности у области дидактике математике био је како мотивисати ученике да размишљају и на својим решењима раде самостално већ у раном узрасту. У свом педагошком раду Јудита Цофман је имала способност да подигне једноставне математичке истине на виши ниво и претвори елементарне чињенице у зрелу науку. Знала је историјску генезу сваког проблема, где је настао и како је решен кроз историју. Сматрала је да је важан разлог за учење математике у школама промовисање независних процеса размишљања и моћи опажања код ученика. А један од начина за увођење младих у свет слободног и независног учења је њихово укључивање у рад на пројектима као што су били њени добро познати интернационални кампови за младе математичаре одржани у Енглеској и Немачкој. Садржај и организација њене чувене књиге „What to solve? - Problems and suggestions for young mathematicians“, као компилацију проблема и решења, разматрани су током разних педагошких семинара као и при решавању проблема у тим камповима. Посебно се истичу њена размишљања и ставови о важности научне области, историје и наставе геометрије који су, на основу њеног богатог искуства као математичарке и професорке, формирани при раду са средњошколцима и талентованим математичарима. За њу је математика, као једна од цивилизацијских најранијих научних дисциплина, била важан сегмент људске културне баштине. Ова чињеница, сматрала је, мора се одразити и на наставу математике - препоручљиво је да се скрене пажња ученицима, кад год се укаже прилика, на историјске позадине области које се обрађују. Историја геометрије је важан део историје математике, не само зато што је геометрија једна од најстаријих грана математике већ и зато што је то прва логички и строго аксиоматски заснована област математике која се учи у школи. У септембру 2001. године Јудита Цофман била је позвана да учествује у раду Департмана за последипломске студије из наставе математике и именована је за професора на Природно-математичком факултету Универзитета Лајош Кошут у Дебрецину (Мађарска), где је преминула 19. децембра исте године .

Кључне речи: Јудита Цофман, настава математике, дидактика математике. 